\title{
Effect of Nitriding Time on the Structural Evolution and Properties of Austenitic Stainless Steel Nitrided Using High Power Pulsed DC Glow Discharge Ar/ $\mathbf{N}_{2}$ Plasma
}

\author{
S. Yang ${ }^{1, *}$, M. Kitchen ${ }^{2}$, Q. Luo ${ }^{2}$, D.N. levlev ${ }^{1}$ and K.E. Cooke ${ }^{1}$ \\ ${ }^{1}$ Teer Coatings Ltd., Miba Coating Group, West Stone House, Berry Hill Industrial Estate, Droitwich, WR9 9AS, UK \\ ${ }^{2}$ Materials and Engineering Research Institute, Sheffield Hallam University, Howard Street, Sheffield S1 1WB, UK
}

\begin{abstract}
A high power pulsed DC glow discharge plasma (HPPGDP) system was employed to perform fast nitriding of AISI 316 austenitic stainless steel in $\mathrm{Ar}$ and $\mathrm{N}_{2}$ atmosphere. In-situ optical emission spectroscopy and Infrared pyrometer measurements were used during the plasma nitriding to investigate the effect of dynamic plasma on the nitriding behaviour. SEM and EDX, XRD, Knoop indentation, and tribo-tests were used to characterise microstructures and properties of the nitrided austenitic stainless steel samples. HPPGDP produced high ionization of both $\mathrm{Ar}$ and $\mathrm{N}_{2}$ in the plasma that corresponded to dense ion bombardment on the biased steel samples to induce effective plasma surface heating and to form high nitrogen concentration on the biased steel surfaces, and therefore fast nitriding ( $>10 \mu \mathrm{m} / \mathrm{hour}$ ) was achieved. Various phases were identified on the nitrided stainless steel samples formed from a predominantly a single phase of nitrogen supersaturated austenite to a multi-phase structure comprising chromium nitride, iron nitride and ferrite dependent on the nitriding time. All the nitrided AISI 316 austenitic stainless steel samples were evaluated with high hardness (up to $17.3 \mathrm{GPa}$ ) and exceptional sliding wear resistance against hardened steel balls and tungsten carbide balls.
\end{abstract}

Received on 31-03-2016 Accepted on 19-04-2016 Published on 13-10-2016

Keywords: Pulsed Glow Discharge Plasma, Nitriding, Austenitic Stainless Steel, Structural Characterization, Tribological Properties.

\section{INTRODUCTION}

Pulsed glow discharge plasma techniques have been extensively studied in the past decades for surface coating [1-2], plasma nitriding [3-4], combination duplex treatment of nitriding plus coating [5-6] and plasma ion implantation [7-8]. Pulsed glow discharge plasmas are known [9-10] to provide high peak voltage and high peak current at the same average power level when compared to normal, constant voltage DC glow discharge plasmas and therefore high ionization and excitation would be expected during the pulsed glow discharge plasma process. In glow discharge plasmas, energetic particles have several effective uses, such as ionetching, ion-cleaning, ion-implantation, and ion-enhanced coating deposition [11-13]. These can be exploited to ensure the treated surfaces have specific properties and microstructures. Another role, 'plasma surface heating', has also been widely recognised [14-17], but has not been studied as extensively in the history of plasma surface engineering.

"Teer Coatings Ltd., Miba Coating Group, West Stone House, Berry Hill Industrial Estate, Droitwich, WR9 9AS, UK; Tel: 441905 827550;

E-mail: shicai.yang@miba.com
An important application area of plasma nitriding treatment is in the surface hardening of austenitic stainless steels. Austenitic stainless steels have been widely used in chemical engineering, energy industry, food industry, medical devices and implants, and many other fields owing to their excellent corrosion resistance [18-20]. Unlike other low alloy steels, austenitic stainless steels are typically $\mathrm{Fe}-\mathrm{Cr}-\mathrm{Ni}$ based multicomponent alloys, in which the $\mathrm{Cr}$ atoms exhibit heterogeneous distribution in the Fe-based face centre cubic (f.c.c.) austenitic lattice because of the preferential $\mathrm{Cr}-\mathrm{Cr}$ bonding [21]. Also because of preferential bonding of nitrogen to chromium [22-24], the nitriding of the Fe-Cr-Ni austenitic stainless steels follows a trapping and de-trapping mode [2527]. The structure of nitrided stainless steel depends strongly on the nitriding temperature. If sufficient atom diffusion mobility is provided at a relatively high process temperature, the nitrided layer comprises a multi-phase structure of chromium nitride $\left(\mathrm{CrN}\right.$ and/or $\left.\mathrm{Cr}_{2} \mathrm{~N}\right)$, iron nitride, and the metallic ferrite phase [28-30]. Such a multi-phase structure possesses high hardness and excellent wear resistance, whereas the corrosion resistance is poor due to the preferential corrosion of the metallic phase. On the other hand, low-temperature plasma nitriding is more promising, in 
which nitride precipitation is prevented because of insufficient atom mobility. Consequently a single phase with supersaturated nitrogen content is formed exhibiting both superior hardness and tribological properties, combined with good corrosion resistance. Initially low temperature nitriding processes were reported in refs. [31-32], when the newly formed $\mathrm{N}$-superaturated phase was called the 'S-phase' for the unknown crystalline structure in the X-ray diffraction database, or 'expanded austenite' characterising it from its substantial lattice expansion when compared to the parent austenitic phase. Great efforts have been made subsequently towards the structural characterization of this attractive phase [33]. Up to now, it has been confirmed that, the expanded austenitic phase still takes the f.c.c. austenitic lattice. The supersaturation of nitrogen leads to a certain tetragonal change of the cubic lattice due to preferentially more expansion of the (200) plane. High density defects, including dislocations and stacking faults, are also observed as a result of lattice expansion induced plastic deformation. The supersaturated nitrogen atoms preferentially bond to the $\mathrm{Cr}$ atoms to form nano-scale $\mathrm{Cr}-\mathrm{N}$ clusters, whereas the $\mathrm{Ni}$ atoms and a fraction of the $\mathrm{Fe}$ atoms still exhibit metallic bonds. In the view of modern materials science, the expanded austenite can be classified as a nano-composite medium consisting of $\mathrm{Cr}-\mathrm{N}$ clusters dispersed in a Fe-Cr-Ni-N matrix $[22,30]$. In particular, the $\mathrm{Cr}-\mathrm{N}$ clusters are short range ordered ionic compounds having coherent lattice relations to the f.c.c. matrix. So far, plasma nitriding treatments of austenitic stainless steels bring about pronounced structural changes and show great impact on the surface properties. On the other hand, there is still lack of experimental research on the effect of plasma process conditions on the nitrided structure.

This paper reports the structure and properties of nitrided austenitic stainless steel AISI 316 as influenced by the nitriding time and the process temperature. Our recent experiments have revealed that, plasma induced surface heating can be used as an effective means to make a surface treatment more efficient, e.g. fast nitriding (up to $60 \mu \mathrm{m}$ depth within 3 hours) on austenitic stainless steel [34]. In the current experiments, the dynamic increase of sample temperature associated with the plasma nitriding process was monitored. Two typical samples, which were plasma nitrided for one hour and three hours respectively at identical plasma conditions, were carefully characterized by means of scanning electron microscopy (SEM), energy dispersive $X$ ray (EDX) spectroscopy, X-ray diffraction (XRD), as well as microhardness testing. Additionally, optical emission spectroscopy (OES) was employed to study the characteristics of the glow discharge in the HPPGDP process. The OES techniques have been employed by other researchers as an in-situ tool in the characterization of glow discharge and in the dynamic control of plasma process so that the process parameters can be established and are repeatable [35-37]. Based on the experiments, the underlying mechanism of the fast plasma nitriding process is discussed.
In addition, an initial tribological investigation of the resulting nitrided stainless steel surfaces is also reported.

\section{EXPERIMENTAL}

\subsection{The High Power Pulsed Glow Discharge Plasma Nitriding Process}

An austenitic stainless steel, AISI 316, was selected for the research. Square samples, $20 \times 20 \times 2 \mathrm{~mm}$, were polished using $1200 \# \mathrm{SiC}$ abrasive papers, and then cleaned using ultrasonic assistance in acetone for ten minutes.

The high power pulsed glow discharge plasma was generated in a cylindrical vacuum chamber with a diameter of $550 \mathrm{~mm}$ and height of $600 \mathrm{~mm}$. Figure 1 shows a schematic section of the configuration, which could be operated either as a conventional multi-magnetron close-field unbalanced magnetron sputtering ion plating (CFUBMSIP) system or without any magnetrons $[34,38]$. The substrate turntable has a diameter of $350 \mathrm{~mm}$ with single fold rotation. The prepared samples were plasma nitrided using the HPPGDP process with the following parameters: The pressure was set at 1.33 $\mathrm{Pa}$ from which glow discharge plasma was ignited. This pressure was contributed by a mixed $\mathrm{Ar}$ and $\mathrm{N}_{2}$ gases at a constant flow ratio of 1:2. Plasma power was set at $3.0 \mathrm{~kW}$ for the nitrided samples used for this analysis. This plasma power can provide sufficiently dense plasma which uniformly cover all the surface of treated substrate. The process time was currently set up to 3 hours to produce an easily detected nitriding sublayer but much longer nitriding process, e.g. more than ten hours, is also possible under identical parameters leading to thicker nitrided sublayer to benefit the treated stainless steel surface with increased load capacity, resistance to stress induced plastic deformation and resistance to wear.

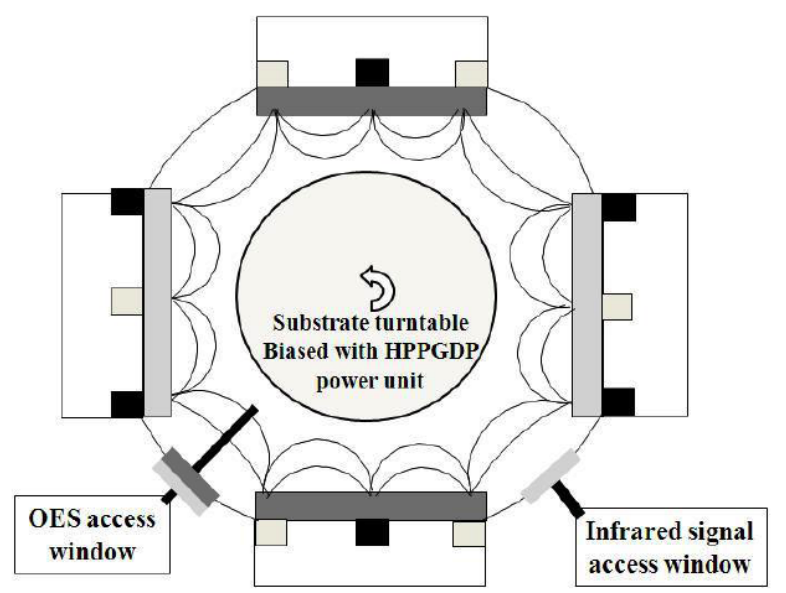

Figure 1: A schematic cross section of the vacuum chamber showing the experimental arrangement for the high power pulsed DC glow discharge plasma process.

An Ocean Optics spectrometer (OCS, Model: HR2000+, with a detection range from 200 to $1100 \mathrm{~nm}$ ) was used to acquire the optical emission spectrum of the plasma to investigate the 
effect of applied plasma power on the sputtering and ionisation behaviour. The installation is shown in Figure 1 where the sensor is inserted in a collimation tube outside the quartz glass observation window and at right angles to the chamber wall. Inside the chamber, there is also another collimation tube with the same axial alignment as that of the external collimator. The tube orientation was targeting the surface of a $\mathrm{Ti}(100 \times 100 \times 10 \mathrm{~mm})$ block and the rotation table was held stationary during optical measurements. Optical radiation emitted from the block surface during a glow discharge process passed through the collimation tubes to the sensor of the spectrometer and then a computer was used to analyse the output of the spectrometer, corresponding to the relevant optical emission wavelengths within the acquired spectra. The total combined surface area of the biased rotation table was estimated to be around 0.3 $\mathrm{m}^{2}$. Ar or $\mathrm{Ar} / \mathrm{N}_{2}$ gases were introduced into the vacuum chamber, the flow adjusted to sustain a pressure of $1.33 \mathrm{~Pa}$ and these conditions were then maintained throughout the HPPGDP process. The turntable was biased by a HPPGDP power generator ( $\mathrm{AE}$ Pinnacle ${ }^{\mathrm{TM}}$ Plus) with the following parameters: power up to $6.0 \mathrm{~kW}$ (equivalent to a maximum power density of $2.0 \mathrm{~W} / \mathrm{cm}^{2}$ or current density of $3.3 \mathrm{~mA} / \mathrm{cm}^{2}$ on substrate), frequency up to $350 \mathrm{kHz}$, positive going pulse width up to $1600 \mathrm{~ns}$, implying a duty cycle of $44 \%$, and an adjustable negative bias potential as low as $-600 \mathrm{~V}$.

Plasma treatments are known to cause surface heating, which would affect the dynamic diffusion of the nitrogen. An Ircon Infrared Pyrometer (Models: MR-6015-03C, 04C and 06C) was used to investigate plasma induced heating as shown in Figure 1. The pyrometer detects infrared radiation signals from the surface of a steel block $(100 \times 100 \times 10 \mathrm{~mm})$ on which it is focused, being effective within the temperature range from $140{ }^{\circ} \mathrm{C}$ to $600{ }^{\circ} \mathrm{C}$. In the measurements, the HPPGDP equipment was operated to heat up the steel block in pure $\mathrm{Ar}$ at a pressure of $1.33 \mathrm{~Pa}$. When the infrared pyrometer indicated a temperature of about $200{ }^{\circ} \mathrm{C}$, the HPPGDP power was switched off to allow the sample to cool down to about $140{ }^{\circ} \mathrm{C}$. Next the plasma power was operated for $2.0 \mathrm{~min}$ (heating up) at a specific power and turned off again for $5.0 \mathrm{~min}$ (cooling down). This heating and cooling cycle was repeated eleven times, with the specific power being increased stepwise from $0.5 \mathrm{~kW}$ to $5.5 \mathrm{~kW}$.

\subsection{Characterization}

The as-nitrided flat surfaces of the austenitic stainless steel samples were characterized for the crystallographic properties, the nitriding induced morphology, and chemical composition. A computer programmed Philips X'Pert X-ray diffraction machine was employed for the crystallographic analyses using an incident X-ray beam of Cu-Ka1 $(\lambda=$ $0.154056 \mathrm{~nm})$. The $X$-ray was generated from a copper anode at supplied power of $40 \mathrm{kV}$ and $40 \mathrm{~mA}$. The samples were analysed both at the Bragg-Brentano $(\theta-2 \theta)$ mode and, to enhance reflection signals from the nitride surface layer, at the $\Omega-2 \theta$ mode with a fixed incident beam angle $\Omega=5^{0}$. In acquiring a diffraction curve, the selected parameters were: diffraction angle $2 \theta=15^{\circ}-100^{\circ}$, step size $0.026^{\circ}$, and a scanning speed $0.021^{\circ}$ per second. The as-acquired diffraction curves were processed by 9-point smoothening, background removal and $\mathrm{K}_{\mathrm{c} 2}$ trimming. A self-developed Gaussian peak-fitting method was applied to make precise measurement of the diffraction peaks, from which the crystalline d-spacings were calculated [39].

A high-resolution analytical scanning electron microscope (SEM), FEI Nova-200 FEG-SEM, was used to observe the surface morphology and microstructure. For the latter, a vertical cross-section was cut from each nitride sample and thermo-mounted. After following a procedure of metallographic grinding and polishing, the polished samples were etched using a $6 \% \mathrm{HNO}_{3}$ solution to make the nitride structure visible. Energy dispersive X-ray (EDX) spectroscopic chemical analysis was also applied both on the as-nitrided surfaces and the prepared cross-sections using the EDX spectroscopy installed on the SEM instrument.

\subsection{Hardness and Tribological Testing}

A Mitituyo $\mathrm{HV} / \mathrm{HK}$ micro-hardness tester was employed to determine the hardness properties using a Knoop indenter. The tester was equipped with a 2-dimensional micrometer platform to record the position of each indent. The surface hardness was tested at an indenting load of $50 \mathrm{~g}$, and at least five measurements were made on each sample to provide an average value and the associated standard deviation. Under such load, the actual indentation depths on the tested samples were between $1.8-2.5 \mu \mathrm{m}$. Lower indenting loads were not selected because of the large data scattering which was due to the roughness induced in the as-nitrided surfaces. The hardness-depth profiles of the two nitride samples were measured on polished cross-sections, in which the long axis of the Knoop indent was kept to a direction parallel to the surface edge in order to achieve the best depth resolution of the profile. For the same reason, the minimum indenting load of $10 \mathrm{~g}$ was applied.

The wear resistance of the processed samples was evaluated using a self-developed pin-on-disc tribo-meter $[34,38,40]$. In the tests, two counterpart materials were used, including $5.0 \mathrm{~mm}$ diameter balls made from hardened $\mathrm{Cr}$ alloyed ball bearing steel and WC-8\%Co cemented carbide. The wear tests were conducted under an applied normal load of $5 \mathrm{~N}$ and linear sliding speed of $0.2 \mathrm{~m} \cdot \mathrm{s}^{-1}$, with each test being run for 60 minutes. After each test, the obtained wear track was evaluated using a ball crater taper section method to determine the wear track depth and the wear coefficient.

\section{RESULTS AND DISCUSSION}

\subsection{Optical Emission Spectroscopy (OES) of $\mathrm{Ar}$ and Ar/Nitrogen Plasma}

Figure 2 shows the OES peaks' profile in the wavelength range from 320 to $850 \mathrm{~nm}$. The optical emission spectra were 
detected from the titanium surface during HPPGDP process in which the glow discharge plasma was started with pure $\mathrm{Ar}$ at a pressure of $1.33 \mathrm{~Pa}$ and with power increased from $1.0 \mathrm{~kW}$ to $4.5 \mathrm{~kW}$. Emission lines of $\mathrm{Ti}$ atoms, $\mathrm{Ti}^{+}$ions, $\mathrm{Ar}$ atoms and $\mathrm{Ar}^{+}$ions were identified in the spectra as according to the NIST Atomic Spectra Database [41]. In addition, a few emission lines were attributed to $\mathrm{Fe}$ and $\mathrm{Cr}$. The presence of $\mathrm{Fe}$ and $\mathrm{Cr}$ emission in the spectra can be explained by sputtering from the surface of nearby stainless steel jigs during the HPPGDP process.
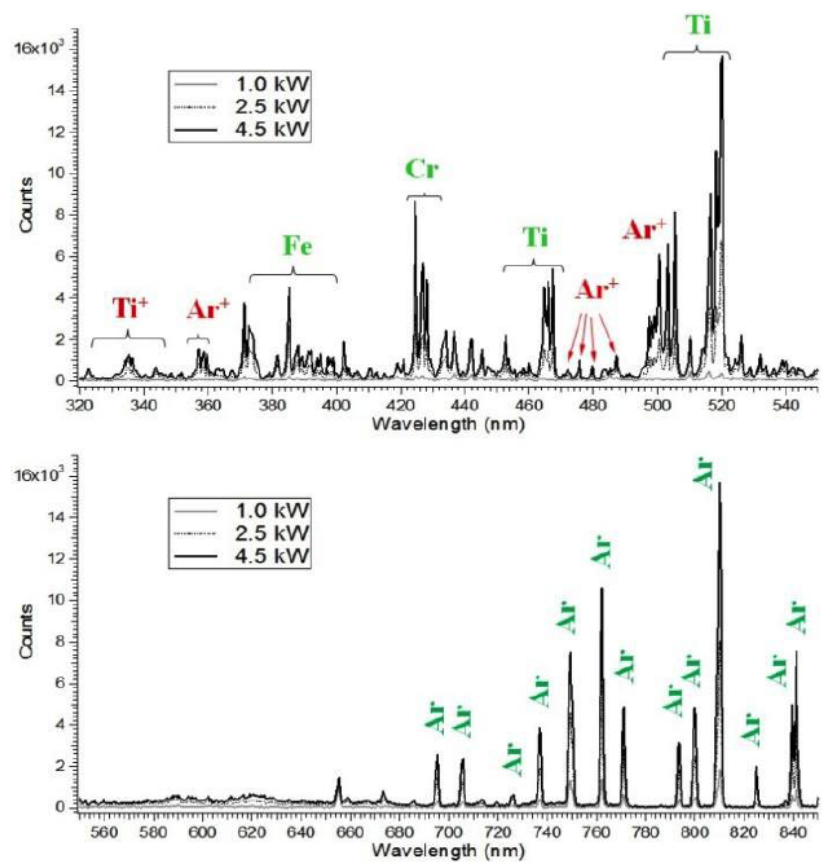

Figure 2: OES peak profiles of a Ti surface recorded at different $\mathrm{Ar}$ glow discharge plasma power.

The intensity of all the spectral peaks were found to increase when the plasma power was increased from $1.0 \mathrm{~kW}$ to 4.5 $\mathrm{kW}$. The spectrum acquired at $1.0 \mathrm{~kW}$ exhibits almost nondetectable peaks of $\mathrm{Ti}$ and $\mathrm{Ar}$ ions except an extremely low peak of $\mathrm{Ar}$ ions at $486 \mathrm{~nm}$ whereas the peaks of the atomic $\mathrm{Ti}$ and $\mathrm{Ar}$ are also of low intensity. When the plasma power was increased to $2.5 \mathrm{~kW}$ and $4.5 \mathrm{~kW}$, increasingly strong ion peaks are observed, e.g. the $\mathrm{Ar}$ ion peaks in the range around $350-370 \mathrm{~nm}$ and $490-510 \mathrm{~nm}$ and the Ti peaks in the $450-470 \mathrm{~nm}$ range.

Similar OES analysis was performed in an atmosphere of mixed $\mathrm{N}_{2}$ and $\mathrm{Ar}$, in which the applied glow discharge power was fixed at $2.5 \mathrm{~kW}$ and the total pressure was maintained at $1.33 \mathrm{~Pa}$. When the $\mathrm{N}_{2}$ to Ar gas flow ratio was increased to 0.11 , the spectrum was changed from $\mathrm{Ar}$ dominated to $\mathrm{Ar}$ plus $\mathrm{N}_{2}$ dominated, Figure 3 . When the $\mathrm{N}_{2}$ to $\mathrm{Ar}$ gas flow ratio was increased to 2.5 , the spectrum exhibited a remarkable increase in the molecular $\mathrm{N}_{2}{ }^{+}$, excited molecular $\mathrm{N}_{2}$ and mono-atomic $\mathrm{N}$ emission lines, and especially a strong $\mathrm{N}_{2}{ }^{+}$ peak was seen at the wavelength of $390 \mathrm{~nm}$. This phenomenon is similar to that reported in [36]. The intensity of the mono-atomic $\mathrm{N}^{+}$emission also appeared to increase with the increasing nitrogen flow, although the corresponding signals were weak and broadened. Furthermore the intensity of the Ti metal and Ar emission lines were found to decrease with the increase of the $\mathrm{N}_{2}$ to $\mathrm{Ar}$ flow ratio in the plasma.

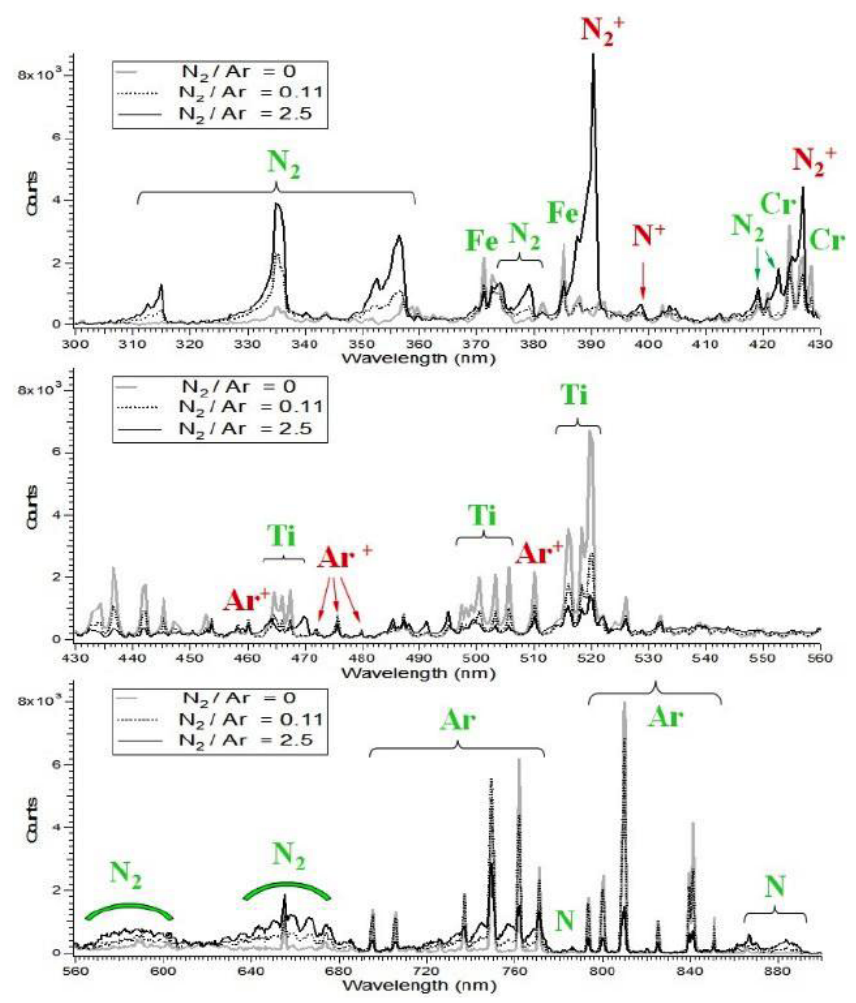

Figure 3: OES peak profile of a Ti surface recorded at fixed plasma power with different $\mathrm{N}_{2} / \mathrm{Ar}$ ratios.

It was reported that energetic particles of either ions or neutral atomic and molecular nitrogen would react with the metal surface to form compounds, e.g. various titanium nitride phases on a Ti substrate [42], or supersaturated solid solution, e.g. the nitrogen-expanded austenite phase on austenitic stainless steel substrates [43-44]. The sputtering yield from the metal surfaces was thus reduced dependent on the $\mathrm{N}$ content in plasma.

The bias current was about $4.7 \mathrm{~A}$ at a plasma power of 2.5 $\mathrm{kW}$ (equivalent to an approximate current density of 1.5 $\mathrm{mA} / \mathrm{cm}^{2}$ on the substrate). This HPPGDP in an Ar- $\mathrm{N}_{2}$ mixed atmosphere produced dense energetic molecular, monoatomic nitrogen ions and "hot" or exited neutrals in the plasma in which those stainless steel samples were immersed. As all the samples were biased by a negative high potential, energetic nitrogen ions were attracted to the sample surface providing sufficient and continuous nitrogen source at the surface ready to be diffused into the sublayer at a suitable temperature condition.

\subsection{Plasma Surface Heating}

Figure 4 shows the effect of the applied plasma heating on the variation of sample temperature, following repeated plasma heating and subsequent cooling over eleven cycles. 
The surface temperature rose immediately after the plasma power was applied and heating was quicker than cooling as shown by the temperature vs time curves for heating were steeper than those seen for cooling. In addition, plasma surface heating at higher plasma powers was faster than that observed at lower plasma power. Cooling, at higher surface temperature, was more rapid than that at lower temperature, presumably due to more efficient radiative cooling. For these dynamic experiments, the temperature at surface of the substrate must have been significantly higher than that inside the bulk of the steel.

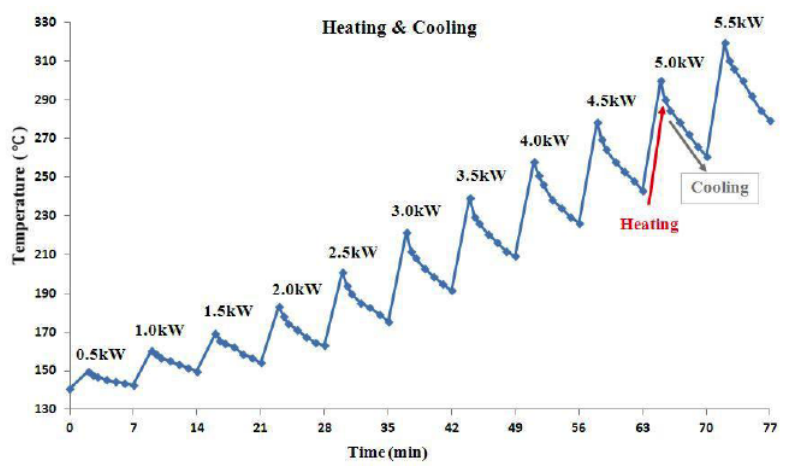

Figure 4: Plasma surface heating and radiant/convection cooling of HPPGDP process operated in pure $\mathrm{Ar}$ at a pressure of $1.33 \mathrm{~Pa}$ (10mTorr).

In Figure 5, the plasma surface heating was measured using a fixed plasma power of $3.0 \mathrm{~kW}$ and different gaseous environments, namely, in pure $\mathrm{Ar}$ and with an $\mathrm{Ar}$ to $\mathrm{N}_{2}$ flow ratio of 1:2 mixture. The surface temperature profiles for both cases appeared to be similar. In general, the surface temperature rose almost linearly up to $360{ }^{\circ} \mathrm{C}$ in the first 10 minutes, and then at a lower rate until it reached about 410 ${ }^{0} \mathrm{C}$ in the next 20 minutes. Afterwards the surface temperature changed even more slowly up to a maximum of about $420{ }^{\circ} \mathrm{C}$ during a further $20 \mathrm{~min}$ and following this, there was hardly any detectable change of surface temperature. Moreover, the surface temperature was about $20{ }^{\circ} \mathrm{C}$ higher in the case of pure $\mathrm{Ar}$ than in the $\mathrm{Ar} / \mathrm{N}_{2}$ mixture, indicating a more moderate plasma intensity in the latter.

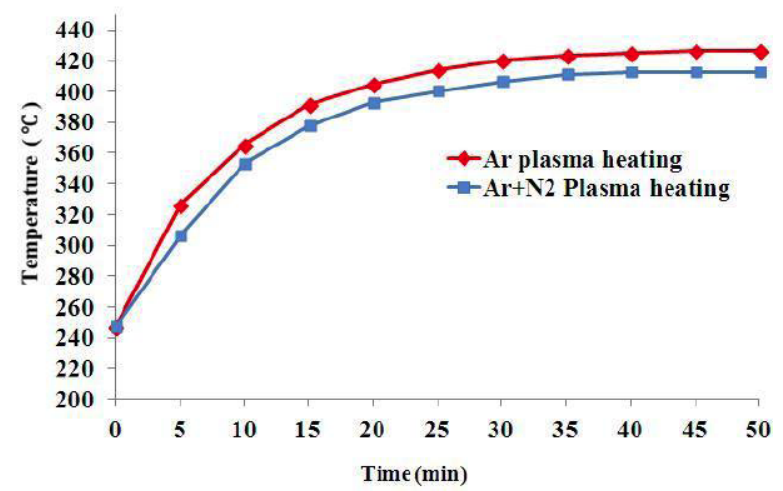

Figure 5: Plasma surface heating at fixed power 3.0kW of HPPGDP process operated in pure $\mathrm{Ar}$ and $\mathrm{Ar}$ to $\mathrm{N}_{2}$ ratio of $1: 2$ at a total pressure of $1.33 \mathrm{~Pa}$ (10mTorr).
$\mathrm{Ar}$ ions are non-reactive particles with relatively large atomic mass unit (40 amu) compared to molecular nitrogen (28 $\mathrm{amu}$ ), and therefore, Ar ions are able to provide more effective energy transfer to substrate surface. It was reported in a Fe-cathode ms-pulsed glow discharge $\mathrm{Ar} / \mathrm{N}_{2}$ plasma [45] that the addition of $1 \%$ nitrogen to the Ar plasma prevented metastable atoms forming in the region near the cathode and resulted in significantly lower $\mathrm{Fe}$ emission after the pulsed peak in the plasma potential compared to that from a pure $\mathrm{Ar}$ plasma at a similar total pressure. It was also reported in the same paper that the densities of $\mathrm{Fe}$ as well as $\mathrm{Cr}$ ions were significantly reduced after adding this amount of nitrogen. Both cases indicated that the ion bombardment contributed by $\mathrm{Ar}$ ions was reduced and therefore this could be a factor in the relative temperature reduction when nitrogen was introduced, in even higher quantities, into the Ar plasma.

The exploitation of plasma surface heating is to create a suitable 'surface temperature' by which nitrogen diffusion could be taken places on the heated surfaces although the components body temperature is far lower than the surface temperature; and this is incorporated with high nitrogen concentration at the heated surface to provide the mechanism for a fast nitrogen diffusion at the treated sublayer.

\subsection{Scanning Electron Microscopy of Nitrided Samples}

Figure 6 shows results of SEM observations and the associated EDX chemical analysis performed on the surfaces of the nitrided austenitic stainless steel samples with process parameters of $3.0 \mathrm{~kW}$, one hour and three hours. In Figure 6a and $\mathbf{6 c}$, the secondary electron (SE) images show equaxial granular morphology of the austenitic steel substrate. Such morphology is believed to be attributed to preferential sputtering of the polycrystalline structure because the fine patterns inside each grain are clear evidence of the ion bombardment. As expected, the 1-hour nitrided sample exhibits less sputter-etching than the 3-hour nitrided sample as the grinding grooves are still visible in the former. Moreover, some grains of the 1-hour nitrided surface exhibit fine straight lines (Figure 6a, arrowed), indicating slip bands caused by plastic deformation taking place in the nitride layer [46-48]. Such slip bands were not observed on the surface of the 3-hour nitrided sample possibly due to the time affecting micro-milling or sputtering etching that modified the surface smoothness making the surface slip bans invisible. The EDX acquired on both samples clearly show a distinct peak of $\mathrm{K}_{\mathrm{a}}-\mathrm{N}$ in addition to the major elements of the steel, Figure $\mathbf{6 b}$ and $\mathbf{6 d}$. Despite the substantial mass absorption of the lowenergy $\mathrm{K}_{a}-\mathrm{N}$ X-ray, the $\mathrm{K}_{u}-\mathrm{N}$ peaks in Figure $\mathbf{6 b}$ and $\mathbf{6} \mathbf{d}$ form significant contrast to the EDX spectrum in Figure 6e, which was acquired in the nitrogen-free steel substrate. Obviously nitrogen in the steel substrate is not detectable. Quantitative results of the EDX analysis are listed in Table 1, noticing the substantial amount of nitrogen in both samples and the slight increase of nitrogen concentration with increasing nitriding time. 


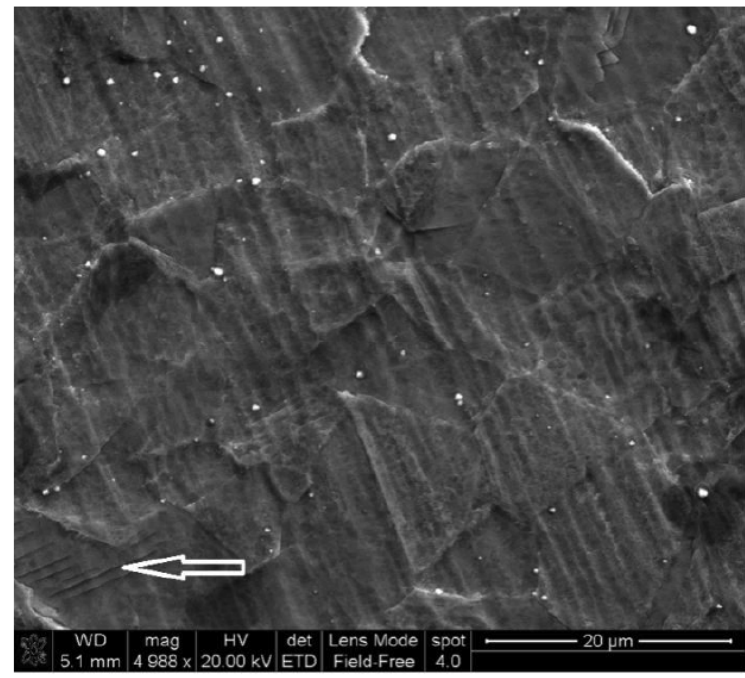

(a)

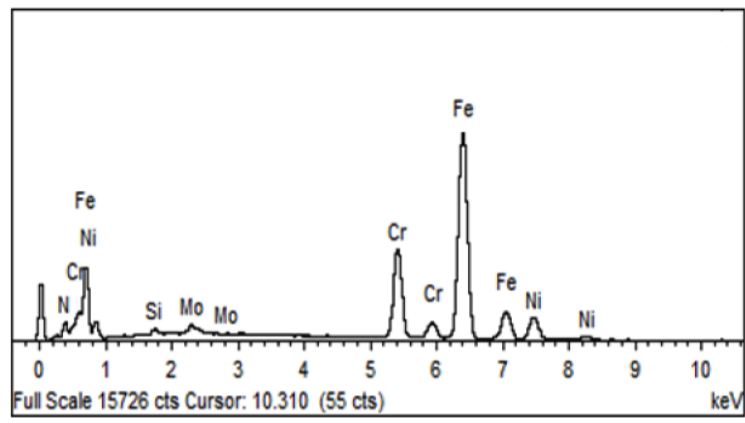

(c)

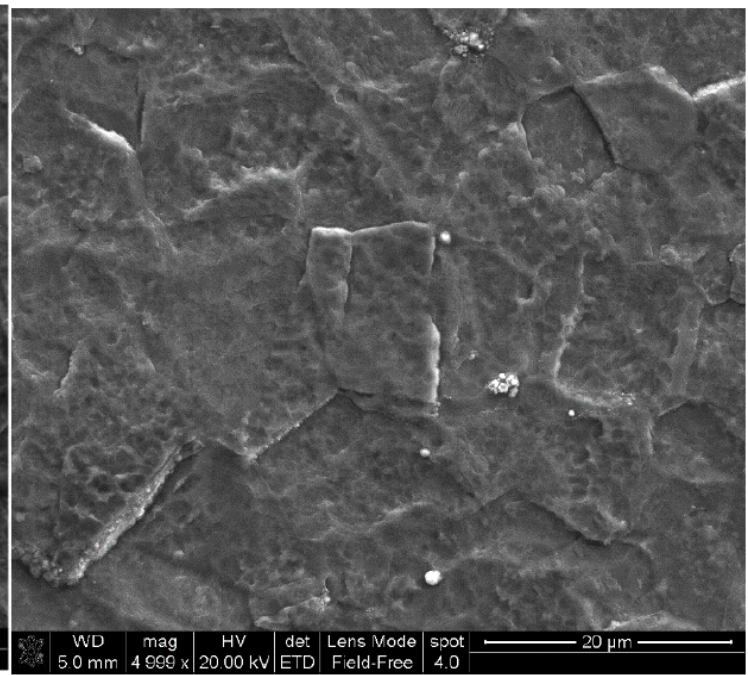

(b)

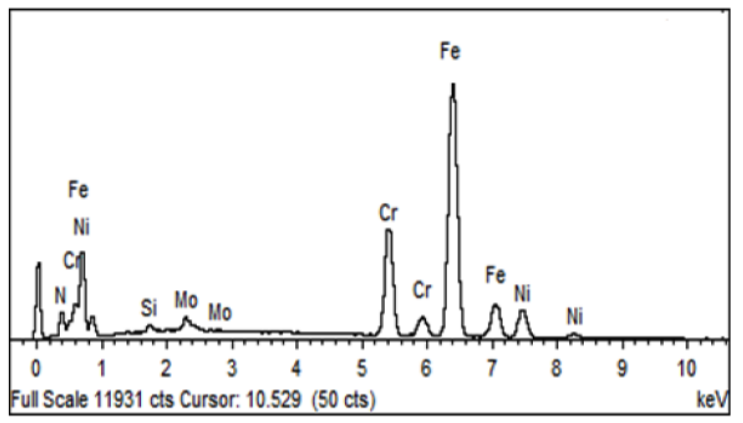

(d)

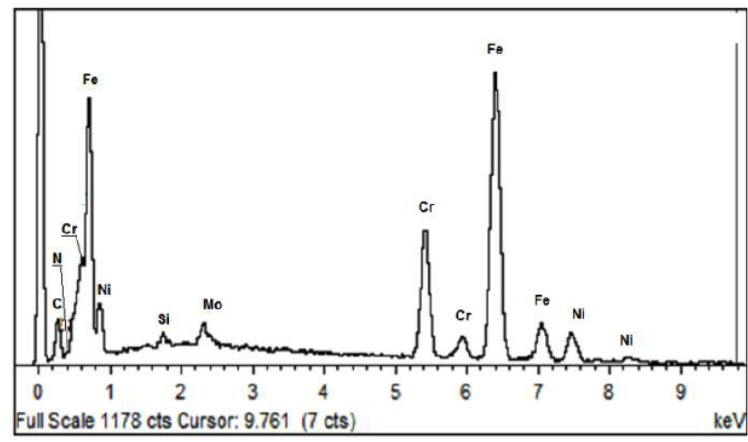

(e)

Figure 6: (a-b) SEM secondary electron micrographs and (c-e) EDX spectra obtained on the nitride surfaces: (a \& c) on 1-hour nitrided steel; (b \& d) on 3-hour nitrided steel; (e) EDX spectrum acquired in the steel substrate at $200 \mu \mathrm{m}$ beneath the nitrided layer interface.

Table 1: Quantitative EDX Analyses of Nitrided Surfaces (unit: at\%)

\begin{tabular}{|c|c|c|c|c|c|c|}
\hline Sample & N & Fe & Cr & Ni & Mn & Mo \\
\hline \hline 1-SS & 28.5 & 47.8 & 13.4 & 7.5 & 0.8 \\
\hline 3-SS & 32.8 & 44.6 & 12.8 & 7.2 & 0.9 \\
\hline
\end{tabular}

1-SS: 1-hour nitrided stainless steel; 3-SS: 3-hour nitrided stainless steel.

More microstructural features were observed on the crosssections, Figure 7. The 1-hour nitrided sample shows a nitrided layer thickness of $12.5 \mu \mathrm{m}$, as evidenced by the lower backscattered electron contrast, Figure 7a. The thickness has grown to about $35 \mu \mathrm{m}$ in the 3-hour nitrided sample, Figure 7c. This suggests a net increase of $22.5 \mu \mathrm{m}$ in the extra two hours. The SEM observations also reveal evolution of microstructure. In Figure $\mathbf{7 a}$, the major area inside the 1-hour nitrided depth is featureless, indicating of a single-phase expanded austenite (to be confirmed later by 


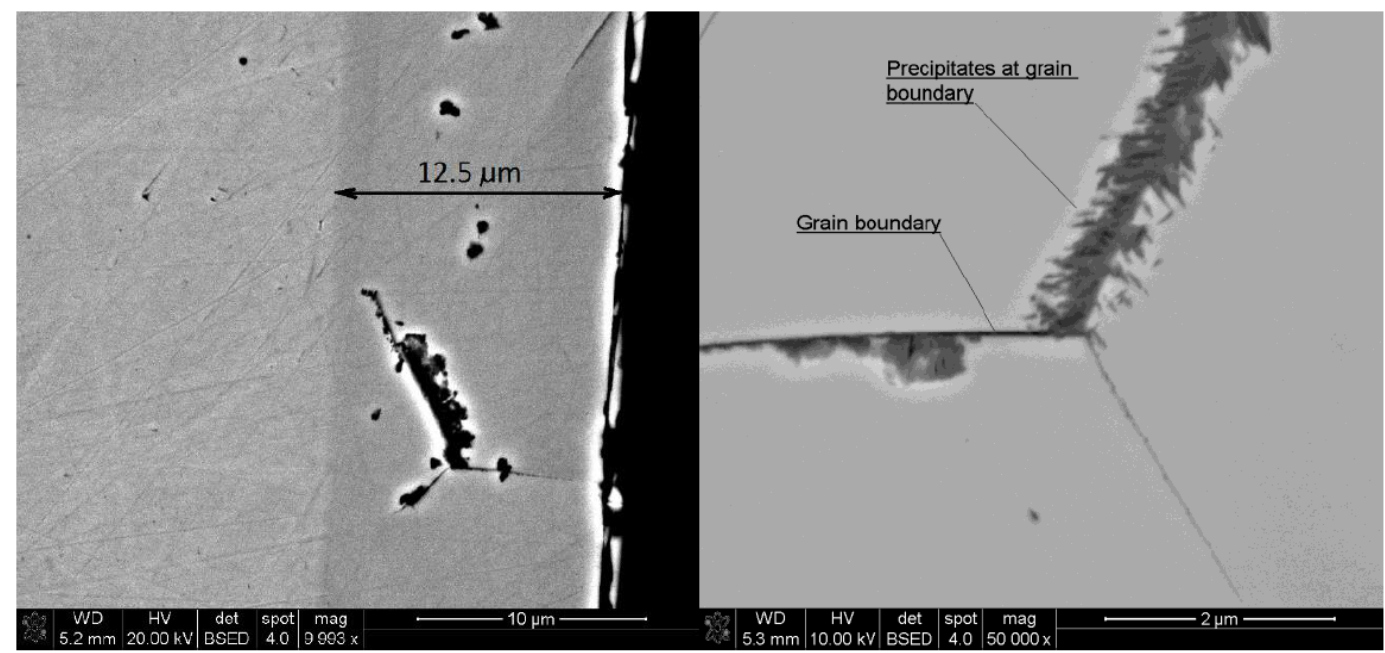

(a)

(b)

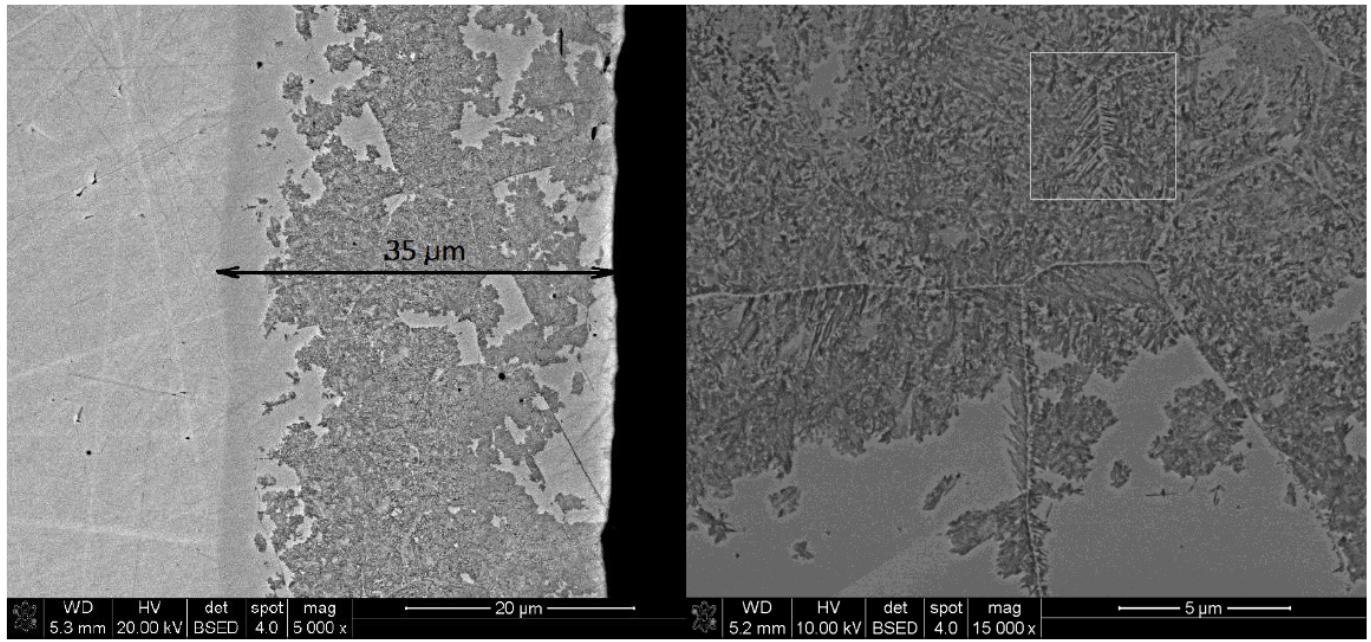

(c)

(d)

Figure 7: SEM backscattered electron micrographs of the polished and etched sections: (a-b) on 1-hour nitrided steel; (c-d) on 3-hour nitrided steel.

XRD). Along the grain boundaries, however, some blackcontrast features suggest the presence of precipitates. The precipitates exhibit short acicular shape, and seem to have nucleated at the grain boundaries and then grown into the grain interiors, Figure $\mathbf{7 b}$. In Figure $\mathbf{7 c}$, approximately $85 \%$ of the 3-hour nitrided layer exhibits a transformation from the expanded austenite single phase to a multi-phase structure. The multi-phase microstructure is shown in more detail in Figure $\mathbf{7 d}$, including the growth of parallel precipitates from the original grain boundaries. In addition, a precipitate-free band exists in front of the nitrided layer, which suggests that the phase transformation took place a certain time after the nitrided layer formation.

It was obvious that high ionization status of the $\operatorname{Ar}$ and $\mathrm{N}_{2}$ mixed species during the plasma nitriding process corresponded to the dense bombardment of energetic ions on the biased samples leading to form high concentration of nitrogen at the sample surface and the same time to give effective plasma 'surface' heating. Consequently fast nitriding of more than $10.0 \mu \mathrm{m} /$ Hour on the stainless steel surface was achieved and the nitriding took place immediately after the HPPGDP was switched on without any additional means of heating for this nitriding process.

\subsection{The Crystalline Structure Determined by XRD Analyses}

Figure 8 shows XRD curves of the 1-hour and 3-hour nitrided samples, which were acquired at a fixed glancing angle $5^{0}$. XRD curves were also acquired and subsequently analysed at the standard $\theta-2 \theta$ mode, not shown here. The diffraction curve of the 1-hour nitrided sample exhibits a typical pattern of expanded austenite (or "S-phase" as it is called by other researchers). These are consistent with the cross-sectional SEM observations in Figure $\mathbf{7 a - b}$, although the precipitates along some grain boundaries were too small to be detectable. By measuring the diffraction peaks, it is possible to quantify the expansion of the crystalline planes with respect to the nitrogen-free austenitic substrate $\left(a_{0}=0.3598 \mathrm{~nm}\right.$ as 


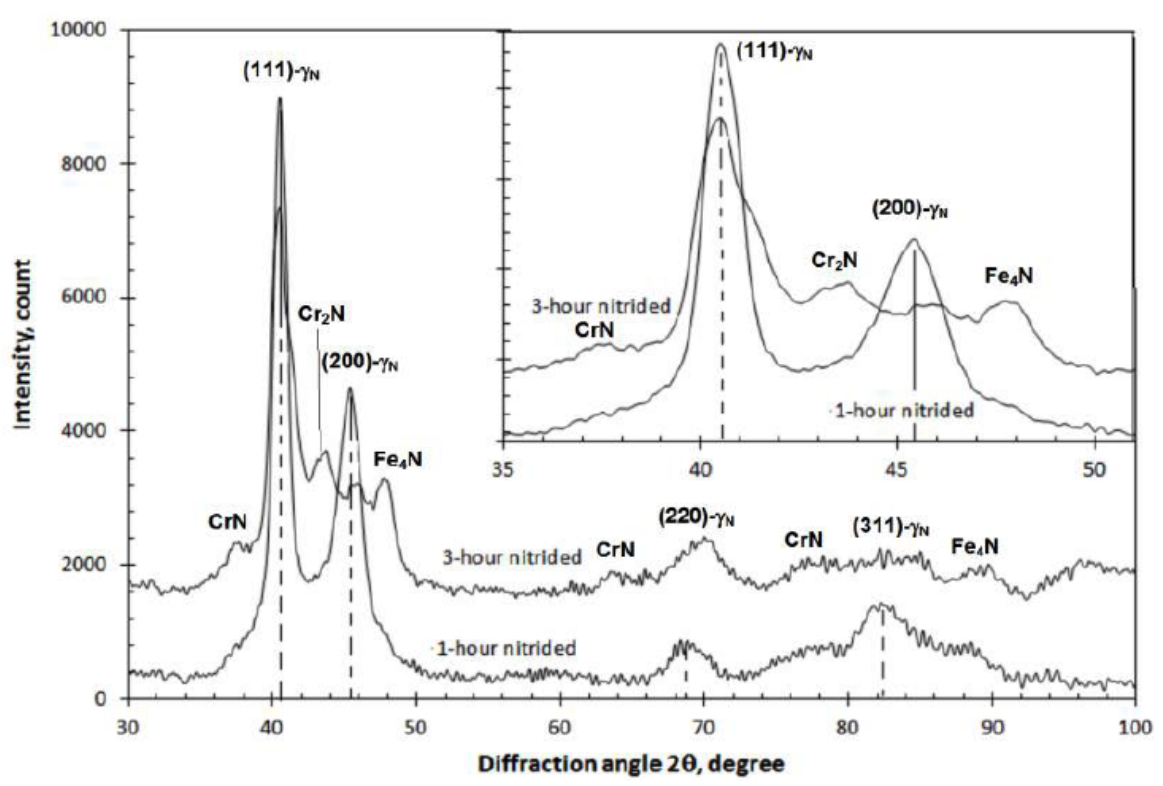

Figure 8: Glancing angle XRD patterns of the 1-hour and 3-hour nitrided steel.

Table 2: Quantified Lattice Expansions of the 1-hour Nitride Sample

\begin{tabular}{|c|c|c|c|c|c|}
\hline \multirow[b]{2}{*}{ (hkl) } & \multicolumn{2}{|c|}{ At $\theta-2 \theta$} & \multicolumn{3}{|c|}{ At $\Omega=5^{0}$} \\
\hline & $\begin{array}{c}\text { d-sp. } \\
\text { nm }\end{array}$ & $\begin{array}{l}\varepsilon, \\
\%\end{array}$ & $\begin{array}{c}\text { d-sp. } \\
\text { nm }\end{array}$ & $\begin{array}{l}\varepsilon, \\
\%\end{array}$ & $\psi$ \\
\hline (200) & 0.2006 & 11.5 & 0.1997 & 11.0 & 17.7 \\
\hline (220) & 0.1398 & 9.9 & 0.1358 & 6.8 & 29.6 \\
\hline (222) & 0.1116 & 7.4 & 0.1106 & 6.6 & 39.2 \\
\hline
\end{tabular}

determined by the same batch of XRD experiments). The results are listed in Table 2, which indicate several interesting characteristics of the expanded austenite layer. In the first, the nitrided layer exhibits pronounced lattice expansion with respect to the substrate, which was attributed to the supersaturated nitrogen as detected by the SEM-EDX analysis (Table 1). Secondly, the measured values of lattice expansion ratio $\varepsilon$ are anisotropic depending on the different $\{\mathrm{hkl}\}$ planes. In particular, the (200) plane exhibited the largest expansion compared to the others. This disproportional lattice expansion could be due to the plasma surface heating that resulted in a temperature gradient especially during the first hour of nitriding, the formation of the nitride layer was initiated from room temperature before rising up to about $420^{\circ} \mathrm{C}$. Activation and diffusion mechanisms for the different crystal sites may well have been stimulated in sequence as the temperature increased. These results are in good agreement with the measurements of other researchers as shown in literature [49-51]. Thirdly, it is noticed that the $\varepsilon$ values measured at the fixed glancing angle are systematically smaller than those measured at the $\theta-2 \theta$ mode. The largest $\varepsilon$ values of the latter suggest compressive residual stresses associated with the nitrogen supersaturation, however further research would be needed to specifically address the associated residual stress measurements.

The XRD curve of the 3-hour nitrided sample, Figure 8, differs remarkably from the 1-hour nitrided sample, for example, the presence of three small sub-peaks after disappearance of the (200) diffraction peak of expanded austenite. The diffraction curve also shows a series of lowintensity and very broad peaks at higher diffraction angle period $60^{\circ}-95^{\circ}$. These peaks fit approximately to several nitride phases of $\gamma^{\prime}-\mathrm{Fe}_{4} \mathrm{~N}, \mathrm{Cr}_{2} \mathrm{~N}, \mathrm{CrN}$ and expanded austenite $\gamma_{N}$ as well as the bcc ferrite. These are in good agreement with the microstructure evolution as observed by crosssectional SEM (Figure 7). The partial decomposition of the expanded austenite can be attributed to the plasma sputtering induced heating effect, being consistent with the reported the nitrided austenitic stainless steels in a high temperature process [28].

\subsection{The Hardness Properties}

Knoop hardness measurements showed that, the surface hardness values of the 1-hour and 3-hour nitrided samples 
are $13.8 \pm 1.3 \mathrm{GPa}$ and $17.3 \pm 1.6 \mathrm{GPa}$ respectively. It should be pointed out that, the hardness property of the 1-hour nitride sample was under-estimated because of the much thinner nitrided layer compared to the other sample. Moreover, one has to bear in mind that the as-measured hardness values included a contribution of the compressive residual stresses. Nevertheless, both samples clearly exhibited effective hardening.

Figure 9 shows the in-depth hardness profiles measured on polished cross-sections of the two samples. The 1-hour nitrided sample shows high hardness of $11-12 \mathrm{GPa}$ in a depth of approximately $13 \mu \mathrm{m}$, whereas the hardness and hardened depth of the 3-hour nitride sample are around 15 GPa and $34 \mu \mathrm{m}$ respectively. Both samples exhibit a sharp change of the hardness values at the interface between the nitrided layer and the substrate.

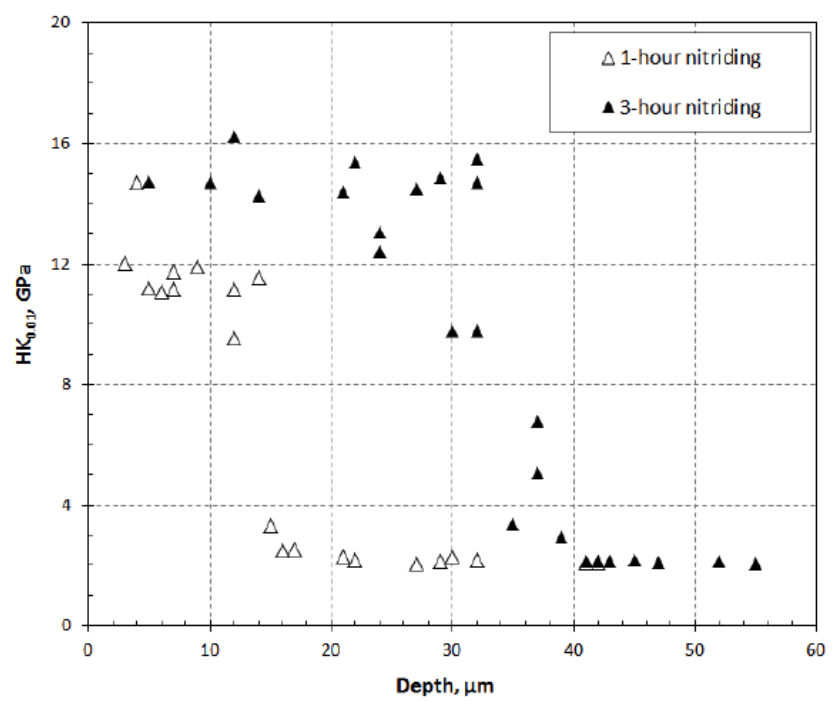

Figure 9: Knoop hardness profiles measured on the cross-sections of the nitrided samples.

It is clear that the high hardness of nitrided austenitic stainless steels is due to the super saturated nitrogen contents in the nitrided sublayers from which the case of one hour nitrided sample was evaluated with concentration of nitrogen at $28.5 \%$ in atomic ratio and formed with expanded austenitic phase (or S-Phase); whilst the case of three hours nitrided sample was characterised to have concentration of nitrogen at $32.5 \%$ and formed with multi-phases including $\varepsilon-\mathrm{Fe}_{3} \mathrm{~N}, \gamma^{\prime}-\mathrm{Fe}_{4} \mathrm{~N}, \mathrm{Cr}_{2} \mathrm{~N}, \mathrm{CrN}$ as well as S-Phase. Both of the cases would correspond to the nitrided sublayers with high hardness.

\subsection{The Sliding Wear Property}

Figure 10 shows wear tracks of the tested samples, in which a ball crater taper section was created on the track in order to measure the wear depth. In the case of as received stainless steel without plasma nitriding, the tests had to be terminated after only a very short sliding time of $\sim 60$ seconds because of seizure and excessive vibration. This was because either the steel or the WC-Co balls caused gross plastic deformation within the wear track immediately after the sliding commenced, resulting in extensive penetration of the ball into the soft steel surface. Deep groves were produced with debris from the stainless steel distributed on the rubbed surfaces. The debris was repeatedly pressed by the passage of the sliding ball forming into flat fragments. The penetration of ball into the rubbed SS surface was about $5.5 \mu \mathrm{m}$ and 12.0 $\mu \mathrm{m}$ deep for hardened steel ball and WC-Co ball respectively. In these cases, the wear rates were estimated to be 5.82 $\times 10^{-13} \mathrm{~m}^{3} \mathrm{~N}^{-1} \mathrm{~m}^{-1}$ against the steel ball and $1.45 \times 10^{-12} \mathrm{~m}^{3} \mathrm{~N}^{-1} \mathrm{~m}^{-}$ ${ }^{1}$ against the WC-Co ball respectively.

A simple calculation was made to estimate the Hertzian contact stresses of the applied ball-on-disk loading conditions: given the applied load of $5 \mathrm{~N}$ and a ball diameter of $5 \mathrm{~mm}$, the maximum compressive stress resulted on the centre of the ball-flat contact is $1,281 \mathrm{MPa}$ for the hardened steel ball, with a maximum shear stress underneath the disk surface estimated to be $\sim 400 \mathrm{MPa}$. Both the estimated contact stress and the maximum shear stress are higher than the yield strength of austenitic stainless steel (approximately $200 \mathrm{MPa}$ in the annealed condition).

In contrast, the wear tests on the nitrided austenitic stainless steel ran for 60 minutes and showed very little wear along with much smoother wear tracks, Figure 10. In both cases, the nitrided surface was able to withstand the applied normal load and tangential load with extremely small volumes of wear as indicated by the small depths of the wear tracks. The average friction coefficients were measured to be 0.5 and 0.7 against the hardened steel ball and the carbide ball respectively. The measured wear depths and calculated wear coefficients are shown in Table 3. When the counterpart ball was hardened steel, the wear coefficient of the nitrided steel was $9.54 \times 10^{-16} \mathrm{~m}^{3} \mathrm{~N}^{-1} \mathrm{~m}^{-1}$. When the counterpart ball was cemented carbide, the wear coefficient was $1.02 \times 10^{-15}$ $\mathrm{m}^{3} \mathrm{~N}^{-1} \mathrm{~m}^{-1}$. Such low values are equivalent to the wear coefficients of transition metal nitride coatings grown by physical vapour deposition [52-53]. The wear coefficients of the nitride austenitic stainless steel determined in current tribo-tests fall also into similar ranges when compared to the results of other researchers, e.g. $6.4 \times 10^{-15} \mathrm{~m}^{3} \mathrm{~N}^{-1} \mathrm{~m}^{-1}$ obtained in self-mating dry sliding wear of low-temperature carbonized $316 \mathrm{~L}$ austenitic stainless steel [54], and $2.8 \times$ $10^{-15} \mathrm{~m}^{3} \mathrm{~N}^{-1} \mathrm{~m}^{-1}$ obtained in dry sliding wear of plasma nitride $316 \mathrm{~L}$ steel against a $\mathrm{Si}_{3} \mathrm{~N}_{4}$ ceramic ball [55].

On the other hand, the wear tracks were developed to certain widths, namely, $390 \mu \mathrm{m}$ against the carbide ball and $546 \mu \mathrm{m}$ against the steel ball. Assuming the wear track widths were equal to the wear scar diameters of the counterpart balls, then the wear coefficients of the balls can be calculated, $4.07 \times 10^{-14} \mathrm{~m}^{3} \mathrm{~N}^{-1} \mathrm{~m}^{-1}$ for the nitrided steel and $2.07 \times 10^{-14}$ $\mathrm{m}^{3} \mathrm{~N}^{-1} \mathrm{~m}^{-1}$ for the carbide ball respectively.

Figure 11 shows SEM observations of the worn surfaces. In Figure 11a-b, the un-nitrided steel wear track exhibits uniform 


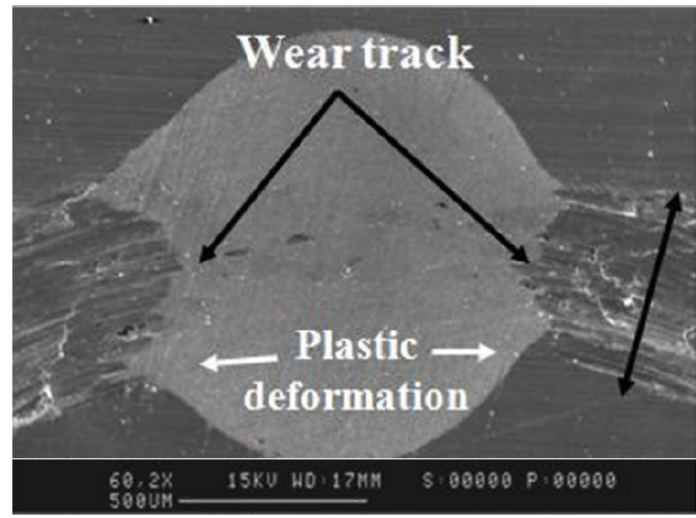

(a)

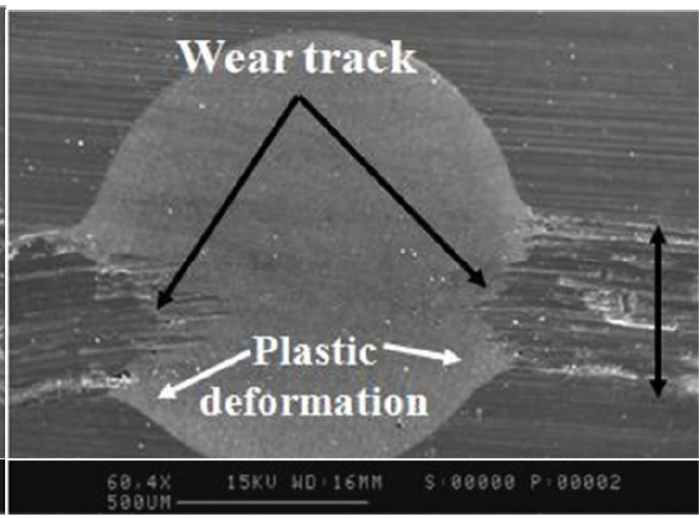

(b)

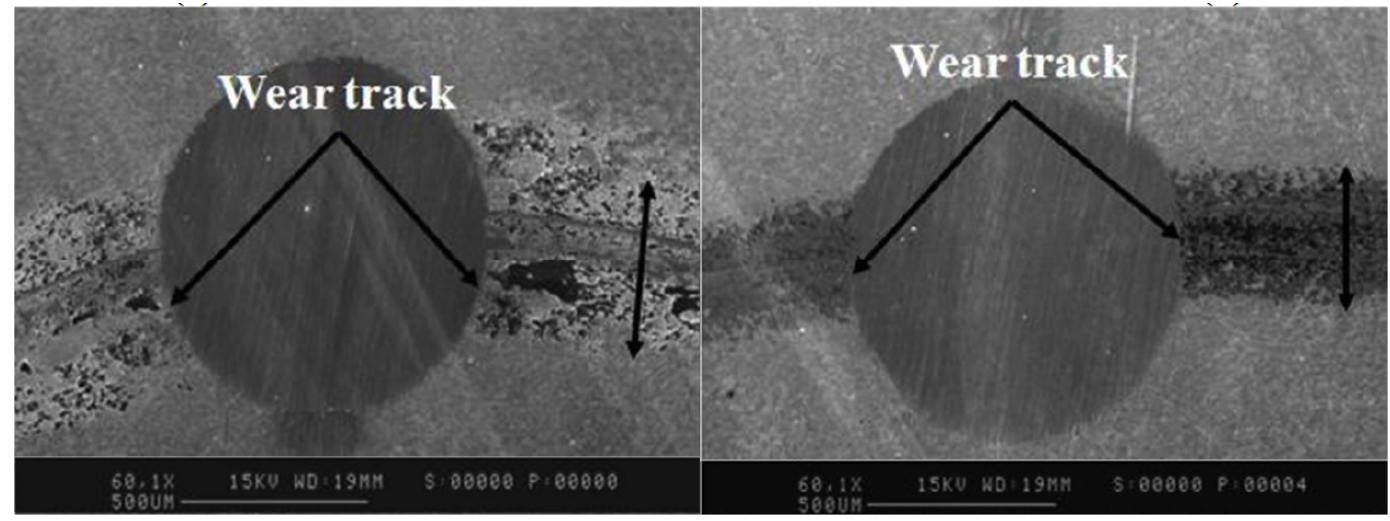

(c)

(d)

Figure 10: SEM images showing ball crater taper section measurements of wear tracks: (a) Un-nitrided steel, hardened steel counterpart; (b) un-nitrided steel, WC/Co counterpart; (c) 3-hour nitrided steel, hardened steel counterpart; and (d) 3-hour nitrided steel, WC/Co counterpart.

Table 3: Friction and Wear Properties of Nitrided Austenitic Stainless Steel

\begin{tabular}{|c|c|c|c|c|c|c|}
\hline Material & Counterpart & $\begin{array}{c}\text { Test time } \\
(\text { minute) }\end{array}$ & Sliding cycles & $\begin{array}{c}\text { Friction } \\
\text { coefficient }\end{array}$ & $\begin{array}{c}\text { Wear depth } \\
(\mu \mathrm{m})\end{array}$ & $\begin{array}{c}\text { Wear coefficient } \\
\left(\mathbf{m}^{3} \mathbf{N}^{-1} \mathbf{m}^{-1}\right)\end{array}$ \\
\hline \hline \multirow{2}{*}{ Nitrided 316L } & Steel & 60 & 28,620 & $\sim 0.5$ & $<0.6$ & $9.54 \times 10^{-16}$ \\
\cline { 2 - 7 } & WC-Co & 60 & 19,080 & $\sim 0.7$ & $<0.6$ & $1.45 \times 10^{-15}$ \\
\hline \multirow{2}{*}{ Bare 316L } & Steel & 1 & 477 & $0.4-0.7$ & 5.5 & $5.82 \times 10^{-13}$ \\
\cline { 2 - 7 } & WC-Co & 1 & 318 & $0.4-0.8$ & 12.0 & $1.45 \times 10^{-12}$ \\
\hline
\end{tabular}

distribution of severe plastic deformation. The deformation is evidenced by sliding grooves, which is easily understood because of the low hardness and good ductility of the austenitic steel. In Figure 11c, the low-magnification image shows a much narrower wear track of the nitrided steel than for the un-nitrided steel. A substantial amount of wear debris was found to agglomerate along the wear track, generated from the wear of the sliding couple surfaces, especially the hardened steel ball. At high magnification, Figure 11d, the worn surface was found to be covered with a thick tribofilm. In particular, the fish-scale pattern of the tribofilm, according to our previous research [56], was related to the severe frictional force. Further investigation of the wear mechanisms of the nitrided surface is scientifically interesting, and will be addressed in the future by high-resolution microscopy and spectroscopy as described in our previous work [53, 56]. Nevertheless, the current tribological experiments have confirmed a significant improvement in the wear resistance of the austenitic stainless steel substrate.

It was known that low temperature $\left(<500{ }^{\circ} \mathrm{C}\right)$ nitrided austenitic stainless steel provided advantages of both better wear and corrosion resistance due to supersaturated nitrogen atoms in the steel forming as expanded austenitic phase resulted in high hardness to against wear and without precipitation of metal nitrids prevented corrosion from grain boundaries $[49,57]$.

It is unavoidable that precipitation of metal nitrides are formed at high nitriding process temperature that reduces the 


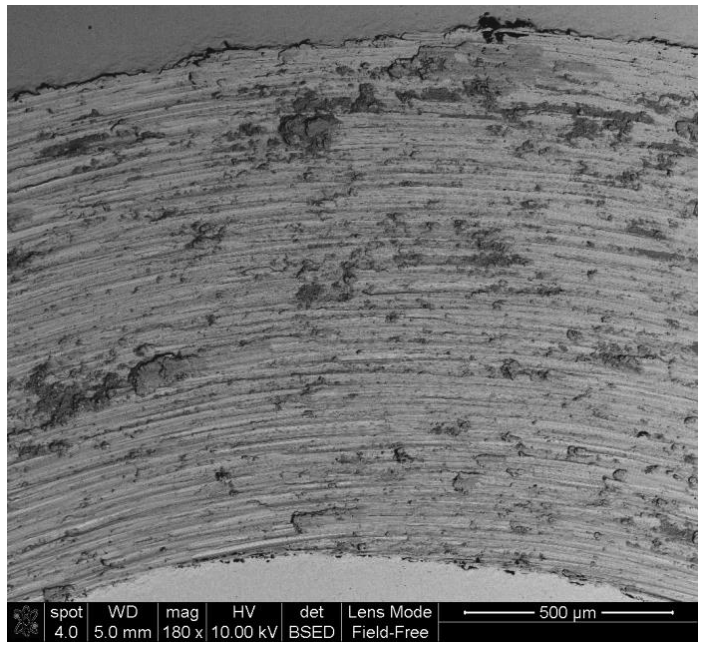

(a)

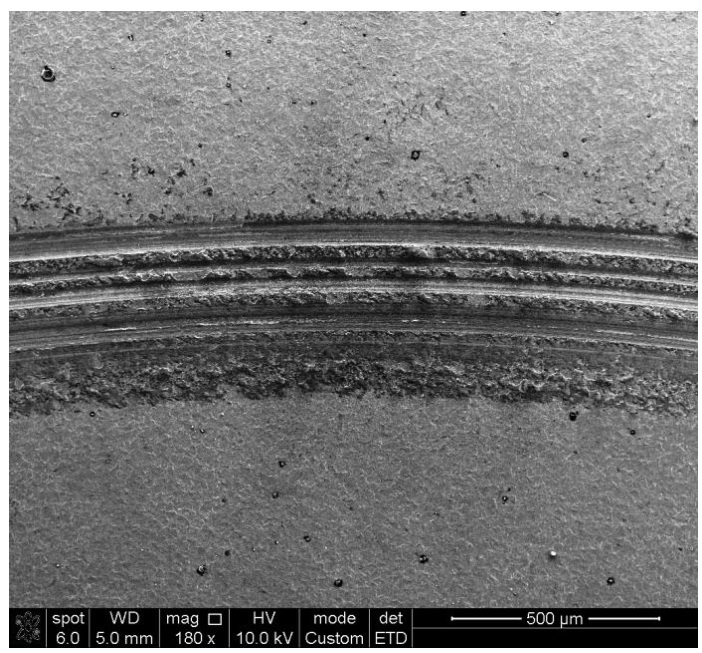

(c)

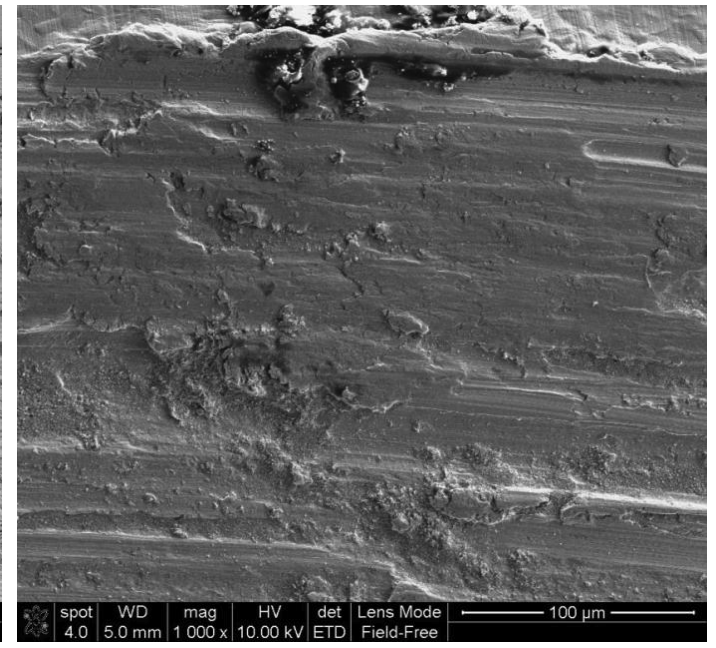

(b)

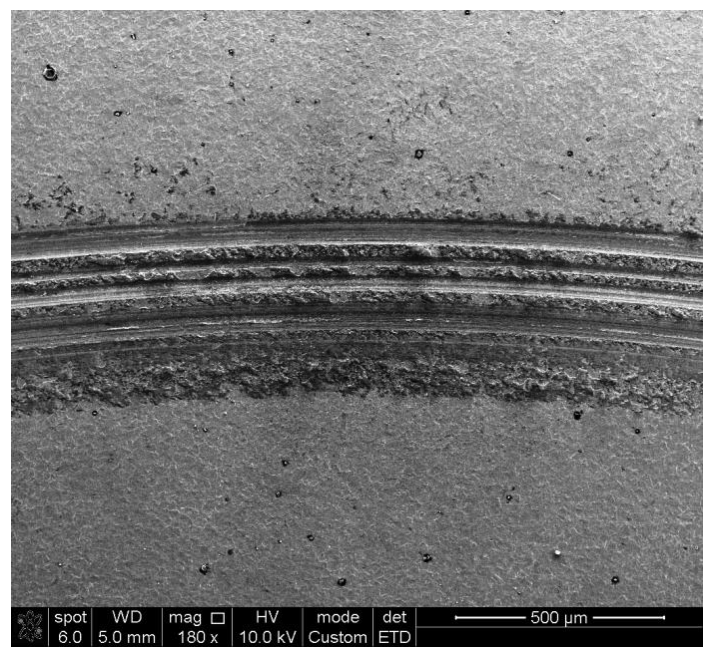

(d)

Figure 11: SEM images of worn surfaces: (a-b) Un-nitrided steel, sliding against hardened steel counterpart; (c-d) 3-hour nitrided steel, sliding against hardened steel counterpart.

performance of corrosion resistance. In our case, infrared pyrometer was used to measure temperature and the infrared single was taken from a large steel block $(100 \times 100 \times 10 \mathrm{~mm})$. Therefor the real temperature on the surface of a small sample $(20 \times 20 \times 2 \mathrm{~mm})$ could be far higher than that indicated at the large component because the much less mass of the small sample was under the similar intense bombardment as that of large component surface. Therefore the real surface temperature on small samples must be much higher than the given temperature so that resulted precipitation of metal nitrides was detected especially from the sample nitrided for three hours.

Interesting thing was that the one hour nitride sample consisted almost pure $S$ phase, and furthermore, even in the three hours nitride sample, the front zoon at the substrate interface appeared to be as the $S$ phase in terms of the cross sectional surface morphology (Figure 7c) although the rest area were formed by multiphase. There was reported [58] that short time $(<60 \mathrm{~min})$ plasma nitriding at high temperature of $520{ }^{\circ} \mathrm{C}$ would form the pure $\mathrm{S}$ phase in the nitrided AISI 316 stainless steel with better corrosion resistance. Thus it is worthwhile to investigate the regime of high temperature fast plasma nitriding from which single $S$ phase nitride austenitic stainless steel could be produced in a short time process but this will be addressed to our future work.

\section{CONCLUSIONS}

High power pulsed glow discharge plasma has been found to enable fast nitriding of austenitic stainless steels. Following the experimental characterization of the pulsed plasma process and the nitrided austenitic stainless steel AISI 316 samples, the following conclusions have been made:

1) The HPPGDP process was shown to be able to ionize gaseous species to generate argon ions, nitrogen ions and their excited neutrals when the input power was increased to $2.5-4.5 \mathrm{~kW}$. 
2) The HPPGDP process was found to result in dense energetic ion bombardment on the high potential biased samples that contributed to forming of high concentration of nitrogen at the sample surface and pronounced plasma induced heating at the same surface to create a mechanism for fast nitrogen diffusion into the treated sublayer.

3) At the applied input power of $3.0 \mathrm{~kW}$, Ar to $\mathrm{N}_{2}$ flow ratio of $1: 2$ and total pressure of $1.33 \mathrm{~Pa}$, the steel surface temperature rose with increase time before it stabilized at 420 ${ }^{0} \mathrm{C}$ as measured in situ. Fast plasma nitriding of $>10 \mu \mathrm{m} / \mathrm{hour}$ was achieved for either the one hour nitriding process during which it was started at room temperature, or the three hour nitriding process during which it was also started at room temperature but stabilized at about $420{ }^{\circ} \mathrm{C}$ after one hour.

4) Short time of one hour nitrided layer showed a surface hardness of $13.8 \mathrm{GPa}$, a supersaturated nitrogen concentration of 28.5 at\%, and predominantly a single phase of expanded austenite. Some initial nitride precipitation was observed along the austenite grain boundaries. On the other hand, the 3-hour nitrided sample showed higher hardness of $17.3 \mathrm{GPa}$, slightly increased nitrogen concentration of 32.8 at $\%$, and a multi-phase structure comprising a mixture of fine nitride precipitates as well as ferrite.

5) In the un-lubricated ball-on-disk sliding tests, the 3-hour nitrided austenitic stainless steel showed exceptional low wear coefficients of $0.95 \times 10^{-15} \mathrm{~m}^{3} \mathrm{~N}^{-1} \mathrm{~m}^{-1}$ (against hardened steel) and $1.45 \times 10^{-15} \mathrm{~m}^{3} \mathrm{~N}^{-1} \mathrm{~m}^{-1}$ (against WC/Co) respectively.

\section{ACKNOWLEDGEMENT}

The authors would sincerely like to acknowledge financial support from the Seventh Framework Program SP1-JTIFCH.2012.3.4 with Grant agreement No 325331 for the project of Steel Coatings For Reducing Degradation in SOFC.

\section{REFERENCES}

[1] Llewellyn IP, Rimmer N, Scarsbrook GA, Heinecke RA. Low temperature pulsed plasma deposition: III. A method for the deposition of aluminium and tin at room temperature. Thin Solid Films 1990; 191: 135-145 http://dx.doi.org/10.1016/0040-6090(90)90279-M

[2] Yukimura K, Mieda R, Tamagakin H, Okimoto T. Electrical characteristics of arc-free high-power pulsed sputtering glow plasma. Surface and Coatings Technology 2008; 202: 5246-5250. http://dx.doi.org/10.1016/j.surfcoat.2008.06.021

[3] Guiberteau E, Bonhomme G, Hugon R, Henrion G. Modelling the pulsed glow discharge of a nitriding reactor. Surface and Coatings Technology 1997; 97: 552-556. http://dx.doi.org/10.1016/S0257-8972(97)00188-6

[4] Rosales I, Martinez H, Ponce D, Ruiz JA. Wear performance of Nballoyed, pulsed plasma nitrided $\mathrm{Mo}_{3} \mathrm{Si}$ intermetallic. International Journal of Refractory Metals and Hard Materials 2007; 25: 250-255. http://dx.doi.org/10.1016/j.jirmhm.2006.06.004

[5] Grün R. Combination of different plasma assisted processes with pulsed d.c.: cleaning, nitriding and hardcoatings. Surface and Coatings Technology 1995; 74-75: 598-603. http://dx.doi.org/10.1016/0257-8972(95)08310-3

[6] Novák $P$, Vojtěch D, Šerák J, Knotek V, Bártová B. Duplex surface treatment of the Nb-alloyed PM tool steel. Surf Coat Technol 2006; 201: 3342-3349.

http://dx.doi.org/10.1016/j.surfcoat.2006.07.101
Blawert C, Mordike BL, Huchel U, Strämke S, Collins GA, Short KT, Tendys J. Surface treatment of nitriding steel 34CrAINi7: a comparison between pulsed plasma nitriding and plasma immersion ion implantation. Surface and Coatings Technology 1998; 98: 1181 1186.

http://dx.doi.org/10.1016/S0257-8972(97)00232-6

[8] Rauschenbach B. Encyclopedia of Materials: Science and Technology 2001; 7023-7027.

[9] Heintz MJ, Hieftje GM. Langmuir-probe measurements of a pulsed and steady-state rf glow-discharge source and of an rf planarmagnetron source Spectrochimica Acta Part B: Atomic Spectroscopy 1996; 51: 1629-1646.

http://dx.doi.org/10.1016/S0584-8547(96)01558-3

[10] Bogaerts A, Neyts E, Gijbels R, van der Mullen J. Gas discharge plasmas and their applications. Spectrochimica Acta Part B: Atomic Spectroscopy 2002; 57: 609-658

http://dx.doi.org/10.1016/S0584-8547(01)00406-2

[11] Schonjihn C, Donohue LA, Lewis DB, Munz WD, Twesten RD, Petrov I. Enhanced adhesion through local epitaxy of transition-metal nitride coatings on ferritic steel promoted by metal ion etching in a combined cathodic arc/unbalanced magnetron deposition system. J Vac Sci Technol 2000; 18: 1718-1723.

http://dx.doi.org/10.1116/1.582414

[12] Schonjihn C, Paritong H, Munz WD, Twesten RD, Petrov I. Influence of the interface composition on the corrosion behaviour of unbalanced magnetron grown niobium coatings on steel. J Vac SciTechnol 2001; 19: 1392-1398.

http://dx.doi.org/10.1116/1.1379319

[13] Hultman L, Munz WD, Musil J, Kadlec S, Petrov I, Greene JE. Lowenergy $(-100 \mathrm{eV})$ ion irradiation during growth of TiN deposited by reactive magnetron sputtering - Effects of ion flux on film microstructure. J Vac Sci Technol 1991; 9: 434-438.

http://dx.doi.org/10.1116/1.577428

[14] Kersten H, Deutsch H, Steffen H, Kroesen GMW, Hippler R. The energy balance at substrate surfaces during plasma processing. Vacuum 2001; 63: 385-431.

http://dx.doi.org/10.1016/S0042-207X(01)00350-5

[15] Akamatsu H, Yatsuzuka M. Simulation of surface temperature of metals irradiated by intense pulsed electron, ion and laser beams. Surf Coat Technol 2003; 169: 219-222. http://dx.doi.org/10.1016/S0257-8972(03)00083-5

[16] Galvao NKAM, Costa BLS, Mendes MWD, de Brito RA, Souza CF, Alves C. Structural modifications of M35 steel submitted to thermal gradients in plasma reactor. J Mater Proc Technol 2008; 200: 115-119. http://dx.doi.org/10.1016/.j.jmatprotec.2007.08.058

[17] Lundin D, Stahl M, Kersten H, Helmersson U. Energy flux measurements in high power impulse magnetron sputtering. L Phys $D$ - Appl Phys 2009; 42: 185202. http://dx.doi.org/10.1088/0022-3727/42/18/185202

[18] Lo KH, Shek CH, Lai JKL. Recent developments in stainless steels Mater Sci Eng 2009; R65: 39-104.

http://dx.doi.org/10.1016/j.mser.2009.03.001

[19] Buhagiar J, Bell T, Sammons R, Dong HS. Evaluation of the biocompatibility of S-phase layers on medical grade austenitic stainless steels. J Mater Sci - Mater Med 2011; 22: 1268-1278. http://dx.doi.org/10.1007/s10856-011-4298-3

[20] Bordjih K, Jouzeau EY, Mainard D, Payan E, Delagoutte JP, Netter P Evaluation of the effect of three surface treatments on the biocompatibility of $316 \mathrm{~L}$ stainless steel using human differentiated cells. Biomaterials 1996; 17: 491-500. http://dx.doi.org/10.1016/0142-9612(96)82723-2

[21] Gavriljuk VG, Shanina BD, Berns H. ON the correlation between electron structure and short range atomic order in iron-based alloys. Acta Mater 2000; 48: 3879-3893.

http://dx.doi.org/10.1016/S1359-6454(00)00192-0

[22] Lei MK, Zhu XM. Chemical state of nitrogen in a high nitrogen facecentred-cubic phase formed on plasma source ion nitride austenitic stainless steel. J Vac Sci Technol 2004; 22: 2067-2070. http://dx.doi.org/10.1116/1.1786305

[23] Moslemzadeh N, Beamson G, Diplas S, Tsakiropoulos P, Watts JF. Monitoring atomic level electronic changes in the alloying of stainless steels with Auger and photoelectron spectroscopy. Surf Sci 2008; 602: $216-225$

http://dx.doi.org/10.1016/i.susc.2007.10.008

[24] Diplas S, Moslemzadeh N, Watts JF, Beamson G, Tsakiropoulos P. An XPS study of the interatomic charge distribution in stainless steels. Surface and Interface Analysis 2010; 42: 722-725.

http://dx.doi.org/10.1002/sia.3367 
[25] Parascandola S, Moller W, Willaimson DL. The nitrogen transport in austenitic stainless steel at moderate temperature. Appl Phys Lett 2000; 76: 2194-2196.

http://dx.doi.org/10.1063/1.126294

[26] Moller W, Parascandola S, Telbizoiva T, Gunzel R, Richter E. Surface processes and diffusion mechanisms of ion nitriding of stainless steel and aluminium. Surf Coat Technol 2001; 136: 73-79. http://dx.doi.org/10.1016/S0257-8972(00)01015-X

[27] Moskalioviene T, Galdikas A, Riviere JP, Pichon L. Modeling of nitrogen penetration in polycrystalline AISI $316 \mathrm{~L}$ austenitic stainless steel during plasma nitriding. Surf Coat Technol 2011; 205: 33013306. http://dx.doi.org/10.1016/i.surfcoat.2010.11.060

[28] Lei MK. Phase transformation in plasma source ion nitride austenitic stainless steel at low temperature. J Mater Sci 1999; 34: 5975-5982. http://dx.doi.org/10.1023/A:1004728711459

[29] Li GJ, Peng Q, Li C, Wang Y, Gao J, Chen SY, Wang J, Shen BL. Effect of DC plasma nitriding temperature on microstructure and drysliding wear properties of $316 \mathrm{~L}$ stainless steel. Surf Coat Technol 2008; 202: 2749-2754. http://dx.doi.org/10.1016/.jsurfcoat.2007.10.002

[30] Martinavicius A, Abrasonis G, Scheinost AC, Danoix R, Danoix F, Stinville JC, Talut G, Templier C, Liedke O, Gemming S, Moller W. Nitrogen interstitial diffusion induced decomposition in AISI 304L austenitic stainless steel. Acta Mater 2012; 60: 4065-4076. http://dx.doi.org/10.1016/i.actamat.2012.04.014

[31] Zhang ZL, Bell T. Structure and corrosion resistance of plasma nitride stainless steel. Surf Eng 1985; 1: 131-136. http://dx.doi.org/10.1179/sur.1985.1.2.131

[32] Ichii K, Fujimura K, Takase T. Structure of the on-nitrided layer of 188 stainless steel. Technical Report Kansai University 1986; 27: 135144.

[33] Dong H. S-phase surface engineering of $\mathrm{Fe}-\mathrm{Cr}, \mathrm{Co}-\mathrm{Cr}$ and $\mathrm{Ni}-\mathrm{Cr}$ alloys. Int Mater Rev 2010; 55: 65-98. http://dx.doi.org/10.1179/095066009X12572530170589

[34] Yang S, Cooke K, Sun H, Li X, Lin K, Dong H. Development of advanced duplex surface systems by combining CrAlN multilayer coatings with plasma nitrided steel substrates. Surf Coat Technol 2013; 236: 2-7. http://dx.doi.org/10.1016/j.surfcoat.2013.07.017

[35] Petitjean L, Ricard A. Emission spectroscopy study of N2-H2 glow discharge for metal surface nitriding. J Physics D: Appl Phys 1984; 17: 919-929 http://dx.doi.org/10.1088/0022-3727/17/5/008

[36] Baravian G, Sultan G, Damond E, Detour H, Hayaud C, Jacquot P. Optical emission spectroscopy of active species in a TiCN PVD arc discharge. Surf Coat Technol 1995; 76-77: 687-693.

http://dx.doi.org/10.1016/02578-9729(68)00077-

[37] Debal F, Wautelet M, Dauchot JP, Hecq M. Spectroscopic optical emission tomography of direct-current magnetron sputtering discharges in argon-nitrogen gas mixtures. Surf Coat Technol 1999; 116-119: 927-932.

http://dx.doi.org/10.1016/S0257-8972(99)00286-8

[38] Luo Q, Yang S, Cooke KE. Hybrid HIPIMS and DC magnetron sputtering deposition of TiN coatings: deposition rate, structure and tribological properties. Surf Coat Technol 2013; 236: 13-21. http://dx.doi.org/10.1016/i.surfcoat.2013.07.003

[39] Luo Q, Chi K, Li S, Barnard P. Microstructural Stability and Lattice Misfit Characteri-sations of Nimonic 263, Proceedings of the ASME 2012 Pressure Vessels \& Piping Di-vision Conference (PVP2012), 2012; 6(Pts A \& B): 197-206.

[40] Yang S, Li X, Renevier NM, Teer DG. Tribological properties and wear mechanism of sputtered $\mathrm{C} / \mathrm{Cr}$ coating. Surf Coat Technol 2001; 142-144: 85-93.

http://dx.doi.org/10.1016/S0257-8972(01)01147-1

[41] [NIST] NIST Atomic Spectra Database: http://www.nist.gov/pml/data/ asd.cfm

[42] Yilbaş BS, ŞahinAZ,Al-Garni AZ, Said SAM, Ahmed Z, Abdulaleem BJ, Sami M. Plasma nitriding of Ti 6Al 4V alloy to improve some tribological properties. Surf Coat Technol 1996; 80: 287-292. http://dx.doi.org/10.1016/0257-8972(95)02472-7
[43] Samandi M, Hedden BA, Smith DI, Collins GA, Hutchings R, Tendys $\mathrm{J}$. Microstructure, corrosion and tribological behaviour of plasma immersion ion-implanted austenitic stainless steel. Surf Coat Technol 1993; 59: 261-266.

http://dx.doi.org/10.1016/0257-8972(93)90094-5

[44] Menthe E, Rie KT, Schultze JW, Simson S. Optical emission spectroscopy of active species in a TiCN PVD arc discharge. Surf Coat Technol 1995; 76-77: 687-693.

http://dx.doi.org/10.1016/02578-9729(68)00077-

[45] Jackson GP, King FL. Probing excitation/ionization processes in millisecond-pulsed glow discharges in argon through the addition of nitrogen. Spectrochimica B 2003; 58: 185-209. http://dx.doi.org/10.1016/S0584-8547(02)00255-0

[46] Yasumaru N. Low-temperature ion nitriding of austenitic stainless steels. Mater Trans JIM 1998; 39: 1046-1052. http://dx.doi.org/10.2320/matertrans 1989.39.1046

[47] Pedraza F, Grosseau-Poussard JL, Abrasonis G, Riviere JP, Dinhut $\mathrm{JF}$. Influence of low energy high fluc nitrogen implantation on the oxidation behaviour of AISI 304L austenitic stainless steel. A Plly Phys 2003; 94: 7509-7520.

[48] Stinville JC, Villechaise P, Templier C, Riviere JP, Drouet M. Plasma nitriding of $316 \mathrm{~L}$ austenitic stainless steel: Experimental investigation of fatigue life and surface evolution. Surf Coat Technol 2010; 204: 1947-1951. http://dx.doi.org/10.1016/i.surfcoat.2009.09.052

[49] Sun Y, Li XY, Bell T. X-ray diffraction characterization of low temperature plasma nitride austenitic stainless steels. J Mater Sci 1999; 34: 4793-4802.

http://dx.doi.org/10.1023/A:1004647423860

[50] Asgari M, Barnoush A, Johnsen R, Hoel R. Microstructural characterization of pulsed plasma nitrided $316 \mathrm{~L}$ stainless steel. Mater Sci Eng 2011; 529A: 425-434. http://dx.doi.org/10.1016/j.msea.2011.09.055

[51] Wu D, Kahn H, Dalton JC, Michal GM, Ernst F, Heuer AH. Orientation dependence of nitrogen supersaturation in austenitic stainless stee during low-temperature gas phase nitriding. Acta Mater 2014; 79: 339-350. http://dx.doi.org/10.1016/i.actamat.2014.07.007

[52] Münz WD, Donohue LA, Hovsepian PE. Properties of various large scale frbricatedTiAIN- and $\mathrm{CrN}$-based superlattice coatings grown by combined cathodic arc-unbalanced magnetron sputter deposition. Surf Coat Technol 2000; 125; 269-277. http://dx.doi.org/10.1016/S0257-8972(99)00572-1

[53] Luo Q, Rainforth WM, Münz WD. Wear mechanisms of monolithic and multicomponent nitride coatings grown by combined arc etching and unbalanced magnetron sputtering. Surf Coat Technol 2001; 146-147: 430-435. http://dx.doi.org/10.1016/S0257-8972(01)01397-4

[54] Qu J, Blau PJ, Jolly BC. Tribological properties of stainless steels treated by colossal carbon supersaturation. Wear 2007; 263: 719-726. http://dx.doi.org/10.1016/i.wear.2006.12.049

[55] Li GY, Wang ZY, Lei MK. Transition of wear mechanisms of plasma spurce nitride AISI 316 austenitic stainless steel against cderamiccounterface. J Tribology - Transactions of The ASME 2012; 134: 011601. http://dx.doi.org/10.1115/1.4005516

[56] Luo Q. Origin of friction in running-in sliding wear of nitride coatings Tribo Letters 2010; 37: 529-539. http://dx.doi.org/10.1007/s11249-009-9548-x

[57] Sun $Y$, Bell T. Sliding wear characteristics of low temperature plasma nitrided 316 austenitic stainless steel. Wear 1998; 218: 34-42. http://dx.doi.org/10.1016/S0043-1648(98)00199-9

[58] Li Y, Wang Z, Wang L. Surface properties of nitrided layer on AISI $316 \mathrm{~L}$ austenitic stainless steel produced by high temperature plasma nitriding in short time. Applied Surface Science 2014; 298: 243-250. http://dx.doi.org/10.1016/i.apsusc.2014.01.177 